\title{
A COMPARISON OF TWO MODES OF DATA COLLECTION Using multidimensional analysis
}

\author{
EQUIVALENCIA ENTRE DOS MODALIDADES DE ENCUESTA \\ Un análisis multidimensional
}

Elena Abascal eabascal@unavarra.es

Departamento de Estadística e Investigación Operativa. Universidad Pública de Navarra. Spain

VIDAL DíAZ DE RADA vidal@unavarra.es

Departamento de Sociología. Universidad Pública de Navarra. Pamplona. Spain

IGNACIO GARCía LAUTRE nacho@unavarra.es

Departamento de Estadística e Investigación. Universidad Pública de Navarra. Pamplona. Spain

M. IsABEL LANDALUCE iland@ubu.es

Departamento de Economía Aplicada. Universidad de Burgos. Spain

\begin{abstract}
Although the literature on survey modes had abandoned comparisons between face-to-face and telephone surveys, having concluded that the results are similar, the current technological and social environment calls for resuming the debate. As well as the problems that arise when the prospective respondent does not own a telephone (or problems accessing mobile phone users), it is also important to bear in mind that a telephone survey places the respondent in a completely different social situation from that of a face-to-face interview. This gives rise to major differences in the responses to surveys where the interviewer is present (face-to-face) and those conducted via telephone. Although numerous studies have analysed this phenomenon, the vast majority of them have used "variable to variable" comparisons, and hence present the inevitable shortcomings of univariate and bivariate analysis. The present study takes a fresh approach, in which all the survey variables are considered jointly using Multiple Correspondence Analysis on a 2005 regional election poll conducted in Galicia, Spain, by the Center for Sociological Research (CIS) (survey number 2.608).
\end{abstract}

\section{KEYWORDS}

Electoral surveys; Face to face survey; Mixed mode surveys; Multiple Correspondence Analysis; Telephone survey.

\section{ResUmen}

La investigación sobre comparación entre encuestas presenciales y telefónicas se ha reducido en los últimos años, concluyendo que los resultados son similares, pero los recientes desarrollos tecnológicos y cambios sociales han llevado a reabrir el debate. Además de los problemas relacionados con la falta de este equipamiento (o la dificultad para acceder a los que lo poseen como es el caso de los teléfonos móviles), es importante tener en cuenta también que la respuesta de una encuesta telefónica supone una situación social totalmente distinta a la respuesta de una encuesta en presencia del entrevistador. Ambas situaciones generan diferencias importantes entre las encuestas respondidas en presencia del entrevistador (cara a cara) y a través del teléfono. Se trata de un fenómeno que ha sido analizado por numerosas investigaciones, si 
bien la gran mayoría han llevado a cabo una comparación "variable a variable", con las limitaciones propias del análisis uni y bivariante. En el presente trabajo adoptaremos una perspectiva diferente, considerando conjuntamente todas las variables del cuestionario. Utilizaremos, para ello, el Análisis de Correspondencias Múltiples sobre una investigación del CIS realizada en el año 2005 sobre las elecciones autonómicas de Galicia (estudio número 2.608).

\section{Palabras Clave}

Análisis de Correspondencias Múltiples; Encuestas electorales; Encuestas presencial; Encuestas telefónicas; Encuestas con modos mixtos.

\section{INTRODUCTION AND RESEARCH OBJECTIVES}

Telephone surveys were first used towards the end of the first third of the 20th century (Massey 1988: 3) in an attempt to reduce interviewer travel costs in such a geographically dispersed society as the United States. Despite some inaccuracies in the estimates obtained from early applications, the use of telephone interviews for survey research purposes has not ceased to grow, especially following the creation and development of computer-assisted telephone interviewing (CATI) systems. The telephone survey has gradually replaced other data collection procedures, particularly face-to-face interviews (Kalton 2000: 5; Tourangeau 2004: 776).

These developments, which have led to the current survey research environment, are based on the underlying premise that the response does not depend on the mode (Willems and Oosterveld 2003: 23). Nevertheless, this premise has never been fully tested in Spain, where no conclusive evidence has been found to show that survey results are indifferent to the choice of data collection method.

The purpose of this paper is to test whether a change in the data collection procedure -and the sampling procedure - through the use of telephone surveys leads to different responses from those obtained in a previous face-to-face survey. In other words, this paper answers the classic question raised by Groves (1989: 502): "Would a telephone survey get the same results as a face-to-face survey?". The analysis will be made on an election poll conducted by the Centre for Sociological Research $(\mathrm{CIS})^{1}$.

Unlike other studies in which the analysis is performed question-by-question, the present study takes a global perspective, using the exploratory factor analysis method known as Multiple Correspondence Analysis (MCA). This global perspective accounts for possible interactions or associations between responses, thus avoiding potential redundancies. The simultaneous examination of all the available information produces findings that would never emerge from the separate analysis of each question or survey item.

\footnotetext{
${ }^{1}$ Assigned to the Ministry of the Presidency, the CIS is an independent entity established to study Spanish society, mainly through public opinion polls. Its present name and organisation date back to 1977 , although its predecessor, the Public Opinion Institute (IOP), was founded in 1963.
} 
The study is divided into two parts. The first part focuses exclusively on the set of socio-demographic variables describing the survey respondents to enable an analysis of whether the result of the final sample structure is similar in both studies (Abascal, Díaz de Rada, García Lautre and Landaluce, in press)2. After verifying the similarity of the samples, the paper proceeds with a global study of the questions designed to explore opinion and behavioural issues, after which the response categories obtained through each survey mode are projected onto the factorial planes. It is upon these planes that we analyse the observed differences between the two procedures.

\section{BACKGROUND. DIFFERENCES BETWEEN FACE-TO-FACE AND TELEPHONE SURVEYS}

As regards representativeness issues, the telephone survey offers easy accessibility to the target population (Groves 1989: 82); the possibility of making repeated attempts to contact the household (Lavrakas 1993: 83-84); ease of identification of units that do not belong to the survey target population (Czaja and Blair 1996: 38); greater randomness of substitutions (use of reserve cases); greater sample dispersion with no cost increase (DeLeeuw 2008: 131-131); and the capacity for contacting certain hard-toaccess social strata. With regard to the quality of the information collected, telephone surveys afford a greater sense of anonymity, which usually translates into a higher degree of sincerity in the responses ${ }^{3}$; less influence by the interviewer (DeLeeuw 2008: 114-115); greater capacity for supervising the interviewer and speedier error detection (Dillman 2008: 166-168), and the possibility of avoiding question contamination (Dillman 2008: 166-168).

All this speeds up the information collection process and the analysis of the results while maintaining low costs, and makes it easier to adapt to the timetables of the survey target population. In the specific domain of political research (or pre-election polls), the telephone survey permits greater proximity to the date of the election, which is a key factor in the accuracy of survey findings.

In Spain, only four published studies have found an equivalence between the estimations of face-to-face and telephone surveys.

The first was carried out in Madrid in 1999 using a questionnaire on health habits and preventive practices (Galán et al. 2004). The study found a 10\%-20\% response variation in eight of the survey variables and over $20 \%$ in one of them. Despite these figures, however, there was significant variation in only four variables, leading the authors to recommend the

\footnotetext{
2 "Specifically, it was found that the composition of the sample is similar in both surveys, even in terms of those variables (level education, job type, etc.) that were not controlled in the sampling design. In addition, not only did both surveys achieve the required crossed quotas, but the respondent typologies as defined by their sociodemographic characteristics were similar in both data collection methods.

${ }^{3}$ Other researchers point to the opposite effect (see, for example, Groves and Kahn 1979: 98-100; Krosnick 1991 and 1999; and Green et al. 2001).
} 
use of telephone interviews to survey these topics due to their low economic cost (half that of a face-to-face survey) and the speed gained in obtaining the results.

The second of the four surveys was carried out in the city of Granada in 2004 (Salinas et al. 2004) using a survey of gamblers. Despite slight differences in income and educational levels - both of which were higher in the telephone survey - none were found to have any impact on the survey objective. The authors underline the lower cost of the telephone survey (five times less than the face-to-face procedure), and the $10 \%$ lower response rate: $54.17 \%$ face-to-face versus $42.74 \%$ by telephone.

The fact that these surveys were conducted in cities, however, may give rise to problems concerning the generalisation of the results. Indeed, neither of these two studies fulfils the recommendations of Bowers and Ensley (2003) regarding the need for both surveys (face-to-face and telephone) to be identical.

The universes for the two other studies conducted in Spain are two autonomous communities: the Basque country and Galicia. Both studies deal with the same topic, specifically political behaviour. One was conducted by the Basque Government Sociological Research Bureau in February of 2005 (Martínez de Luna 2008) and the other by the CIS a few weeks prior to the last regional elections in Galicia (May and June 2005).

In the Basque Country study, Iñaki Martínez de Luna (2008: 16) reported higher partial item non-response figures ("don't know" and "no answer") in both past vote recall and voting intention in telephone surveys, but found no variation in questions relating to issues other than these (Martínez de Luna 2008: 16) despite the fact that telephone surveys typically present a higher non-response rate.

By placing its databank at the disposal of researchers (www.cis.es), the CIS study has generated the largest amount of additional research on this issue. Thus, for example, Méndez Lago and Martínez Casiello (2007) ran a comparative study of estimations observed by the two different survey methods and found that the best estimation is yielded by a joint analysis of all the replies given by those surveyed, irrespective of the method by which they were obtained. In another investigation based on the data supplied by that same study, Díaz de Rada (2007) notes that it is more difficult to contact a respondent for a face-to-face survey ${ }^{4}$, but shows it to be the better method for obtaining reliable unemployment and employment rate estimates.

There are a large number of references to this topic outside of Spain. It is also worth noting that many of them have refuted the "fundamental premise" mentioned earlier, finding both data collection tools to be equally reliable.

Thus, for example, in their analysis of the USA 1998 NES (National Election Study) report, Wessell et al. (2000:4) report that respondents to the telephone survey were younger, more highly educated, higher earners, and showed a higher rate of unemployment, while there was no major variation in terms of marital status, stability of residence

\footnotetext{
${ }^{4}$ The telephone survey required an average of 6.6 contacts per subject, versus the 9 required for the face-to-face survey.
} 
and home ownership (similar conclusions were reached by Ellis and Krosnick 1999). A more conclusive study conducted by Green et al. (2001) reported that telephone surveys achieve a poorer representation of the population, especially its less advantaged segments (low earners, the less educated, the elderly, members of racial minorities, etc.). The greater vulnerability of these groups results in a higher rate of refusal to participate in telephone surveys. Telephone surveys obtain a lower quality of response, whether quality is measured by the number of unanswered questions, acquiescence, or response variability. At the same time, they generate a lower level of cooperation and commitment to the interview, along with higher dissatisfaction due to the length of the questionnaire. People show greater reluctance towards answering surveys over the phone and a have stronger tendency to give socially acceptable answers than when interviewed face-toface (Groves and Kahn 1979: 98-100).

More recent studies (Voogt and Saris 2005) ask whether the combined use of different procedures might bias the results. The starting point of their study is that non-voters (abstainers) are much more inclined (more willing) to participate in face-to-face surveys than telephone surveys (Biemer 2001; Day et al. 1995; De Leeuw and Van der Zouwen 1988; Goyder 1985; Hox and De Leeuw 1994). Other research has shown that face-toface surveys tend to increase (overestimate) socially acceptable responses (Presser and Stinson 1998; Sykes and Collins 1988).

Nicolaas et al. (2000) conducted a study to test the suitability of surveys to explore electoral attitudes in the UK. This is not a trivial issue in a country where $21 \%$ of the population, a segment characterised by low social status and distinct political behaviour, does not possess a telephone. Another feature of the country is that one in three telephone numbers are ex-directory ${ }^{5}$. The study in question showed that a change in the data collection procedure and the sampling method (through the use of telephone surveys) leads to a change in the replies given previously in the face-to-survey.

We conclude this section by pointing out that, in addition to their individual shortcomings, the studies cited have a common drawback: the data collection methods were compared "variable to variable", in contrast to this study, which proposes a global analysis. While most of the literature compares the distribution of variables in face-to-face versus telephone respondents, this analysis seeks to obtain an overall picture showing all the differences at once. This global approach serves as a complement to analyses based on the examination of individual items. The simultaneous analysis of all the available data enables the extraction of conclusions that would be impossible to obtain through the separate analysis of each survey question or item. It also provides a graphic image of the pattern of relationships between items, thus accounting for any positive or negative associations that may exist between them. On graphs obtained by means of MCA some

\footnotetext{
${ }^{5}$ Telephone subscribership in Spain is very high (98\% in 2005 and $99.3 \%$ in 2009) and the ex-directory rate in 2004 was little more than 10\% overall (Alvira 2004: 46). France had an ex-directory rate of $16 \%$ in 2004, and Beck et al. (2004) report that the exclusion of non-directory numbers has very little impact on overall results.
} 
groups of items appear close together (suggesting that they have positive associations), while others appear at opposite sides of the graph (suggesting that they have negative associations), thus revealing possible response tendencies.

\section{RESEARCH METHOD}

In contrast to the studies mentioned above, our proposal is to perform a conjoint analysis of all the questions in a survey questionnaire where one half of the sample was surveyed in a face-to-face interview and the other half by telephone. Subsection 3a contains a description of the data selected for comparison, subsection $3 \mathrm{~b}$ presents the hypotheses to be tested and subsection $3 c$ gives a brief overview of the operational principles of Correspondence Analysis.

\section{3.a. The Surveys}

The universe for the pre-election survey conducted by the $\mathrm{CIS}$ during the run-up to the Galicia regional elections of June 19, 2005 (survey number 2,608) consists of the adult population (18 years of age and over) of both sexes who were eligible to vote in the Galicia regional elections. The fieldwork took place between May 26 and June 5, 2005 using both data collection methods in conjunction: personal or face-to-face surveys and telephone surveys using the CATI system. A total of 1,600 interviews were performed with each method. To facilitate comparisons, it was decided that the samples in both cases should be taken from the same sampling area.

A random route sampling method was used to select the households for the face-toface interviews, while the numbers for the telephone interviews were selected at random from local telephone databases. Gender and age quotas were applied to ensure a representative sample. All the interviews were held in the homes of the interviewees.

The 3,200 interviews gave a sample error of $\pm 1.8 \%$ for the overall sample at the $95.5 \%$ confidence level (two sigmas), and $\mathrm{P}=\mathrm{Q}=0.5 \mathrm{~A}$ stratified conglomerate multistage sampling method was used with proportional random selection of the primary (municipalities) and secondary (districts) sampling units. The strata were obtained by province and size of population, for which 5 categories were considered: up to 2,000; 2,001-10,000; $10,001-50,000 ; 50,001-100,000$, and over 100,000. Interviews were held in 83 municipalities; 19 in A Coruña, 23 in Lugo and Ourense, and 18 in Pontevedra.

The questionnaire comprised 24 questions and 73 variables. The first five questions had to do with the economic and political climate and the main problems currently affecting Galicia. These were followed by a series of questions designed to analyse the importance of the 2005 regional elections in relation to previous ones by asking respondents how important the election was for them and to what extent they hoped to see a change of government. The following set of questions dealt with electoral behaviour, including intention to vote, party they would vote for if elections were held the 
next day, and, in the event of no precise answer to the last question, sympathy towards the different political parties ${ }^{6}$. There were then several questions relating to (Galician) nationalist sentiment, and left-wing/right-wing ideology. The socio-demographic questions considered were gender, age, level of education, employment status (employed, retired, unemployed, member of the non-active population), province of residence and size of municipal population.

\section{3.b. Hypotheses}

The way in which the questionnaire is administered may affect the quality of the data collected due to modifications in the replies arising from the peculiarities of the interaction that takes place under each procedure. The purpose of this study is to explore whether the questions specific to the research topic, political attitudes and behaviour in the case in hand, are affected by the choice of survey mode. The initial hypothesis is that the content variables, attitudes and political behaviours are, in this case, invariant to the choice of survey mode. The overall nature of the replies (to the full set of questions) is similar when using either mode. To test this hypothesis, we analysed and compared the mean response profiles in the two survey modes.

\section{3.c. Method of Analysis: Multiple Correspondence Analysis}

The method used in this paper to jointly analyse all the questions included in the questionnaire is Multiple Correspondence Analysis (MCA), also known as Homogeneity analysis. It is a multivariate technique developed by Jean-Paul Benzécri in the 1970s and based on the idea that "the model should follow the data, not the inverse". It was later brought up to date and further developed by his disciples, particularly L. Lebart and B. Escofier.

MCA is an appropriate factor-analysis method for the study of interdependence between category or qualitative variables. It is a technique that reaches further than variable relation analysis by revealing the actual structure of the relationship. In addition, it generates graphs based on the association between the categories analysed and the observations, thus providing a global view of the phenomenon under study.

MCA is a statistical tool that enables the analysis of a population of $I$ individuals described by $J$ category variables with a total of $K$ categories. It is clear from the large number of studies published over the last 30 years that one of the most common applications of MCA is the joint processing of survey data ${ }^{7}$.

\footnotetext{
${ }^{6}$ That is, when respondents fail to mention any specific party.

${ }^{7}$ The basis of the MCA of survey data is that every $j$ question constitutes a category variable in which the categories are the response options from which the respondent has to choose one. Thus, the survey comprises three elements: individuals, variables and categories (or response items) that can be loaded into a unique data table and analysed jointly.In practice, the data are used to create a Burt's table, which is a juxtaposition of the con-
} 
The purpose of MCA as a factor analysis method is to extract the basic information from the data while removing noise. This is done by condensing the original data into a smaller space, while minimising information loss and maximising interpretative potential. In MCA, data is condensed by making use of the relations between the response categories in order to obtain new variables known as factors or factorial axes. The graphical representation of these axes provides a simple way to visualise the most relevant information contained in the data. Each axis is interpreted according to the response categories of the various questions analysed, their percentage contribution to the axis formation and the quality of the representation of the categories on the axis.

Once the graphs are plotted, other information can also be represented on them (Lebart et al. 1998). "These additional variables are called "supplementary" or "illustrative" variables as opposed to the "active" variables of the analysis, which determine the solution space. Supplementary variables have no influence on the geometric orientation of the axes; rather, they support and complement the interpretation of the configuration of active variable categories" (Blasius and Greenacre 2006).

As already stated, the aim of the study is to obtain a global, comparable and accessible presentation of the response patterns obtained through the two survey methods. Application of MCA provides factorial axes representing a compromise between the two surveys on to which the categories of the opinion variables (irrespective of the survey procedure) are projected. The response categories obtained by each method are represented on these axes as supplementary variables. A response category represents respondents holding that particular view or exhibiting that particular political behaviour. Exploration of these graphs - using the quality indicators provided by the method- is very useful for the analysis of question content rather than mode effects. The MCA graph shows the relative magnitude of the mode and thus complements classic research aimed only at determining whether or not the effect is significant. Closeness between the points for the same response categories in the different survey settings will suggest that respondents coinciding in that option will also give similar replies to the rest of the questions, whereas wide dispersion between response categories in the two survey settings will signal variation in the replies and indicate its direction. Abascal and Grande (2005) describe how to analyse surveys using MCA. For more information on the method see Grenacre and Blasius (2006).

The comparative analysis of the survey content presented in the following section was carried out using SPAD software (www.spadsoft.com).

tingency tables containing the set of categories or items taken 2 by 2 . Element $I_{q k}$ in the Burt's tables represents the number of individuals that simultaneously choose category $q$ of variable $/$ and category $k$ of variable $j$. Burt's table may be plotted on the $R^{k}$-dimensional space. The factor analysis of the Burt's table gives a set of plane images of approximately the same shape as the cloud of points in the original $R^{k}$-dimensional space. These plane images should be such that the distances between the points is as near as possible to the distances in the original cloud in a K-dimensional space. The factors drawn from the MCA are the set of artificial metric variables most closely related to the set of category variables and serve to create plane images also known as factorial planes. 


\section{A COMPARATIVE ANALYSIS OF THE SURVEY CONTENT}

Recall that the aim in this section is to analyse the degree of similarity of the replies obtained to the questionnaires in each survey setting. A prior study (Abascal, Díaz de Rada, Garcia-Lautre and Landaluce, in press) found similarities between the demographic characteristics of the respondents in a face-to-face survey and in a telephone survey. The question is whether such similarities will also be reflected in the remaining variables of the questionnaire. What will happen with the "political" (henceforth "content") variables considered in the survey?

The variables being analysed in the case in hand relate to opinions regarding the political and economic situation and political preferences, specifically the 13 variables shown in Table 1. Demographics (Table 2 supplementary variables) play only a supporting role, that is, they are used to aid the interpretation, but do not participate in the formation of the factorial axes.

Table 1 shows the questions included in the analysis and the terminology used in the graphic representation of the response categories.

MCA was carried out to obtain a global analysis of all the respondents, irrespective of the mode in which they were surveyed. This revealed factorial axes that provide the compromise frame of reference between the two surveys and enable their comparison on the same factorial plane. This, in turn, yielded graphic representations allowing an analysis of the variation between the different groups of respondents defined by the nature of their replies to the questions and the method employed to obtain them.

Both surveys were also analysed separately in order to verify that the factorial axes of the global analysis serve as a common frame of reference. In other words, a separate analysis confirmed that a global analysis provides a valid representation of both surveys. Consequently, replies to the questions of both surveys can be plotted simultaneously in the global axes due to the fact that their structures, while not identical, are sufficiently similar ${ }^{8}$. In this context, the global factorial axes are also called common or compromise axes.

The response categories to the content questions in the two surveys are situated on the compromise axes, thus enabling their comparison and an analysis of the variation.

This representation is obtained by taking the data from each of the surveys separately and projecting them as supplementary variables as shown in Illustration 1. This gives a three- point graph for each response category, where the points represent the respondents that chose that category in each survey mode (face-to-face and telephone) and overall (total interviewers).

In Figure 1, the response categories for all the questions appear on the first two axes

${ }^{8}$ The graph structures can be taken to be similar if the clouds of points are similar. Thus, we will consider the structures to be similar if the factor interpretation shows both sets of results to be mutually consistent or the projection of the cloud of points resulting from one survey onto the factors extracted from the other reveals a strong correlation between the two. 
Table 1.

Description of the analysed part of the questionnaire and their markers on the plane.

\begin{tabular}{|c|c|c|}
\hline Question and identifier & Response categories & Marker \\
\hline $\begin{array}{l}\text { Q1: How would you describe the current economic } \\
\text { situation in Galicia? } \\
\text { Economic Situation }\end{array}$ & $\begin{array}{l}\text { Very good } \\
\text { Good } \\
\text { Average/Neither good nor bad } \\
\text { Bad } \\
\text { Very bad } \\
\text { Don't know } \\
\text { No answer }\end{array}$ & $\begin{array}{l}\text { ES-VG } \\
\text { ES-G } \\
\text { ES-A } \\
\text { ES-B } \\
\text { ES-VB } \\
\text { ES-DK } \\
\text { ES-DA }\end{array}$ \\
\hline $\begin{array}{l}\text { Q2: Do you consider the current economic situation in } \\
\text { Galicia to be much better, better, the same, worse or } \\
\text { much worse than four years ago? } \\
\text { Economic Past }\end{array}$ & $\begin{array}{l}\text { Much better } \\
\text { Better } \\
\text { The same } \\
\text { Worse } \\
\text { Much worse } \\
\text { Don't know } \\
\text { No answer }\end{array}$ & $\begin{array}{l}\text { EP-MB } \\
\text { EP-B } \\
\text { EP-S } \\
\text { EP-W } \\
\text { EP-Mw } \\
\text { EP-DK } \\
\text { EP-NA }\end{array}$ \\
\hline $\begin{array}{l}\text { Q3: How would you describe the current political situa- } \\
\text { tion in Galicia? } \\
\text { Political Situation }\end{array}$ & $\begin{array}{l}\text { Very good } \\
\text { Good } \\
\text { Average/Neither good nor bad } \\
\text { Bad } \\
\text { Very bad } \\
\text { Don't know } \\
\text { No answer }\end{array}$ & $\begin{array}{l}\text { PS-VG } \\
\text { PS-G } \\
\text { PS-A } \\
\text { PS-B } \\
\text { PS-VB } \\
\text { PS-DK } \\
\text { PS-DA }\end{array}$ \\
\hline $\begin{array}{l}\text { Q4: Do you consider the current political situation in } \\
\text { Galicia to be much better, better, the same, worse or } \\
\text { much worse than four years ago? } \\
\text { Political Past }\end{array}$ & $\begin{array}{l}\text { Much better } \\
\text { Better } \\
\text { The same } \\
\text { Worse } \\
\text { Much worse } \\
\text { Don't know } \\
\text { No answer }\end{array}$ & $\begin{array}{l}\text { PP-MB } \\
\text { PP-B } \\
\text { PP-S } \\
\text { PP-W } \\
\text { PP-Mw } \\
\text { PP-DK } \\
\text { PP-NA }\end{array}$ \\
\hline $\begin{array}{l}\text { Q5a: In your view, of the problems listed on this card, } \\
\text { which is the most important affecting Galicia at the } \\
\text { present moment? And the next in importance? } \\
\text { 1st problem }\end{array}$ & $\begin{array}{l}\text { Unemployment } \\
\text { Public safety } \\
\text { Drugs } \\
\text { Infrastructure } \\
\text { Environmental conservation } \\
\text { Don't know } \\
\text { No answer }\end{array}$ & $\begin{array}{l}\text { 1pUnemp. } \\
1 \mathrm{pPs} \\
1 \mathrm{pDrg} \\
1 \mathrm{plnfra} . \\
1 \mathrm{pEc} \\
1 \mathrm{p}-\mathrm{DK} \\
1 \mathrm{p}-\mathrm{NA}\end{array}$ \\
\hline $\begin{array}{l}\text { Q5a: And the next in importance? } \\
\text { 2nd problem }\end{array}$ & $\begin{array}{l}\text { Unemployment } \\
\text { Public safety } \\
\text { Drugs } \\
\text { Infrastructure } \\
\text { Environmental conservation } \\
\text { Don't know } \\
\text { No answer }\end{array}$ & $\begin{array}{l}\text { 2pUnemp. } \\
2 \mathrm{pPs} \\
2 \mathrm{pDrg} \\
2 \mathrm{plnfra} . \\
2 \mathrm{pPc} \\
2 \mathrm{p}-\mathrm{DK} \\
2 \mathrm{p}-\mathrm{NA}\end{array}$ \\
\hline
\end{tabular}


Table 1.

(cont.)

\begin{tabular}{|c|c|c|}
\hline $\begin{array}{l}\text { Q6: As you know, on next June 19th, Galicia will hold } \\
\text { parliamentary elections. Please say whether you consi- } \\
\text { der these elections more important, equally important or } \\
\text { less important than previous regional elections. } \\
\text { Elections }\end{array}$ & $\begin{array}{l}\text { This more important } \\
\text { Equally important } \\
\text { Elections less important } \\
\text { Don't know } \\
\text { No answer }\end{array}$ & $\begin{array}{l}\text { E-MI } \\
\text { E-EI } \\
\text { E-LI } \\
\text { E-DK } \\
\text { E-NA }\end{array}$ \\
\hline $\begin{array}{l}\text { Q7: Do you think a change of government in Galicia } \\
\text { would be desirable? } \\
\text { Change }\end{array}$ & $\begin{array}{l}\text { Change-Yes } \\
\text { Change-No } \\
\text { Don't know } \\
\text { No answer }\end{array}$ & $\begin{array}{l}\text { Change- } \\
\text { Yes } \\
\text { Change- } \\
\text { No } \\
\text { Change- } \\
\text { DK } \\
\text { Change- } \\
\text { NA }\end{array}$ \\
\hline $\begin{array}{l}\text { Q11: How would you vote if the elections were held } \\
\text { tomorrow? } \\
\text { Vote }\end{array}$ & $\begin{array}{l}\text { PP (People's Party) } \\
\text { BNG (Nationalist party) } \\
\text { PSdG-PSOE (Socialist party) } \\
\text { EU/IU (United Left) } \\
\text { Another party } \\
\text { Blank vote } \\
\text { Would not vote } \\
\text { Don't know } \\
\text { No answer }\end{array}$ & $\begin{array}{l}\text { PP } \\
\text { BNG } \\
\text { PSOE } \\
\text { EU/IU } \\
\text { V.Another } \\
\text { V.Blank } \\
\text { Don't vote } \\
\text { Vote-DK } \\
\text { Vote-NA }\end{array}$ \\
\hline $\begin{array}{l}\text { Q15: Please indicate how likely you are to vote in the } \\
\text { coming elections, using a scale of } 0 \text { to } 10 \text {, where } 0 \\
\text { means "I will definitely not vote" and } 10 \text { means "I will } \\
\text { definitely vote". } \\
\text { Abstention }\end{array}$ & $\begin{array}{l}\text { 1-2 (A. definitely) } \\
\text { 3-4 (A. probably) } \\
\text { 5-7 } \\
\text { 7-8 (A. unlikely) } \\
\text { 9-10 (A. very unlikely) }\end{array}$ & $\begin{array}{l}\text { AbsVD } \\
\text { AbsP } \\
\text { AbsA } \\
\text { AbsU } \\
\text { AbsVU }\end{array}$ \\
\hline $\begin{array}{l}\text { Q19: With respect to Galician nationalist sentiment, } \\
\text { please indicate your position on a scale of } 1 \text { to } 10 \text {, } \\
\text { where } 1 \text { stands for "minimum nationalist sentiment" and } \\
10 \text { stands for "maximum nationalist sentiment". } \\
\text { Nationalist }\end{array}$ & $\begin{array}{l}1-2 \\
3-4 \\
5-7 \\
7-8 \\
9-10 \\
\text { Don't know /No answer }\end{array}$ & $\begin{array}{l}\text { N1-2 } \\
\text { N3-4 } \\
\text { N5-7 } \\
\text { N7-8 } \\
\text { N9-10 } \\
\text { NDK/NA }\end{array}$ \\
\hline $\begin{array}{l}\text { Q22: When discussing politics it is common to speak } \\
\text { in terms of a left and a right wing. On this card you will } \\
\text { see a series of boxes going from left to right. Which box } \\
\text { would you say reflects your political position? } \\
\text { Left-right }\end{array}$ & $\begin{array}{l}\text { 1-2 (far left) } \\
\text { 3-4 (left) } \\
\text { 5-7 (middle) } \\
\text { 7-8 (right) } \\
\text { 9-10 (far right) } \\
\text { Don't know } \\
\text { No answer }\end{array}$ & $\begin{array}{l}\text { L.R-FI } \\
\text { L.R-L } \\
\text { L.R-M } \\
\text { L.R-R } \\
\text { L.R-Fr } \\
\text { L.R-DK } \\
\text { L.R-NA }\end{array}$ \\
\hline
\end{tabular}


Illustration 1.

The tables of data analysed in the MCA of the whole sample of subjects showing the supplementary variables displayed in each case.

\begin{tabular}{|c|c|c|c|c|}
\hline & Content var. & Content var. & Content var. & $\begin{array}{l}\text { Socio-demogr. } \\
\text { var. }\end{array}$ \\
\hline $\begin{array}{l}\text { FACE TO } \\
\text { FACE }\end{array}$ & \multirow{2}{*}{$\begin{array}{l}\text { ACTIVE } \\
\text { TABLE }\end{array}$} & $\begin{array}{l}\text { FACE TO FACE } \\
\text { SUPPLEMENTARY } \\
\text { TABLE }\end{array}$ & EMPTY & \multirow{2}{*}{$\begin{array}{c}\text { SOCIO- } \\
\text { DEMOGRAPHIC } \\
\text { SUPPLEMENTARY } \\
\text { TABLE }\end{array}$} \\
\hline TELEPHONE & & EMPTY & $\begin{array}{c}\text { TELEPHONE } \\
\text { SUPPLEMENTARY } \\
\text { TABLE }\end{array}$ & \\
\hline
\end{tabular}

Figure 1

Plot of response categories for the entire sample (all respondents) on the main factorial plane resulting from the MCA of the active variables)

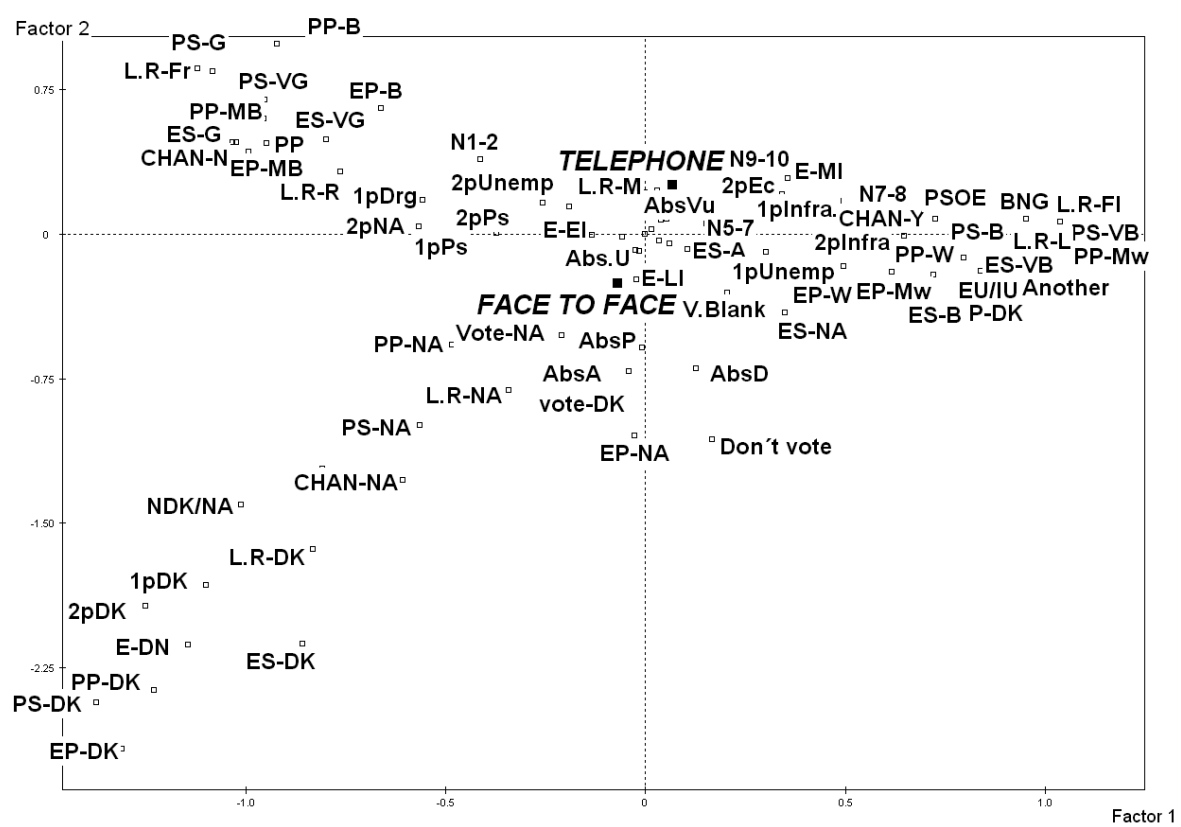

The symbols are explained in Table 1.

Source: Authors' own calculations using data from the CIS (2005). 
of the global analysis. The figure shows the factorial plane with the main discrepancies and similarities among the 1,599 face-to-face and the 1,605 telephone interviewees. This graph captures $80 \%, 57 \%$ on the first axis and $23 \%$ on the second of the non-trivial part of the data analysed (after correction with Benzécri's formula, Benzécri 1979). The interpretation of this plane, which will be addressed later, will provide a very complete picture of the survey.

The plot depicted in Figure 1 shows the three opinion groups. The first group -located in the second quadrant- contains the optimists (those who judge the economic and political situation to be favourable and better than four years before), the conservatives (who do not wish for a change of government and would vote PP9) and the non-nationalists. The second group -located on the positive side of the first axis- groups together the left-wing pessimists (who judge the economic situation to be bad, and the political situation to be worse than four years before, variables which are arranged in order of importance in the definition of the first factor), and the nationalists who express a desire for a change in the governing party (they would vote $\mathrm{PSOE}^{10}$ or BNG ${ }^{11}$ ). Finally, the third quadrant includes those who decline to comment, have no opinion (mainly those who say they "don't know" when asked to assess the political and economic situation, state their ideology or express their feelings towards nationalism, those who have no opinion with respect to political change, or those who do not know which party they would vote for, etc.)

It is worth noting the closeness of the (supplementary) points that capture the average profile in each survey setting (telephone and face-to-face). If the mean response profile to the overall set of questions analysed is the same for both survey modes, the two points (one representing the mean opinion of the face-to-face survey, the other that of the telephone survey) will coincide. Nevertheless, their coordinates on the plane, both on the first axis (factor 1 ) and the second axis (factor 2 ) are significantly different from zero (a p-value of 0.00005 on the first factor and 0 on the second). However, despite the differences being significant (recall the large sample size), they are small in magnitude. In fact, they are barely discernible since both points are so close to the origin. These points show a greater difference on the second axis than on the first; the interpretation for this being mainly due to the no-answer categories. The results of the two surveys are not identical: the face-to-face mode produces a higher "don't know" rate. The hypothesis being tested must therefore be rejected because small but significant differences are found between the results obtained by the two different procedures. These differences will now be examined in more detail.

On the same factorial plane, but in separate graphs for ease of reading, Figures 2 and 3 show the response categories for 8 of the survey questions differentiated by

\footnotetext{
${ }^{9}$ People's Party, right-wing.

${ }^{10}$ Spanish Socialist Worker's Party, left-wing.

${ }^{11}$ Galician Nationalist Bloc
} 
survey mode in order to measure the distance of each from the global result ${ }^{12}$. Each of these elements is marked with an "f" or a " $t$ " to indicate which survey mode was used, while the "global" category (that is, the share for the total number of interviews) remains exactly the same as in the previous figures. This figure provides a clear picture of the variation by survey mode by showing how far each respondent shifts in a given category between settings. For ease of interpretation, a line is sometimes used to show the shift between categories, as for example with respect to the economic situation, "don't know" (lower left-hand quadrant), or ideology "don't know".

The analysis of figures 2 and 3 therefore allows us to conclude, firstly, that, in all categories, the telephone survey located "higher" than the rest (the face-to-face and global sample), thus suggesting that their opinions are clearer, more precise, and more defined ${ }^{13}$. Their location towards the right reveals a more pessimistic view than that identified by the face-to-face and global surveys.

Special attention should be given to the lower left-hand quadrant where the subjects' "undefined" responses are located. The "don't know" and "no answer" response categories for the various questions posed in the face-to-face survey appear grouped together and at a great distance from the origin of the coordinates, while in the telephone survey these categories show greater dispersion. It is worth giving a moment of thought to the implication of this "greater dispersion". Bearing in mind that these categories share the common characteristic of the "impreciseness" of the replies ("don't know" and "no answer"), and that they appear very close together in the face-to-face survey, this proximity suggests that it was nearly always the same subjects that answered "don't know" in all the survey questions (lower quality of response).

However, when these categories are analysed in the telephone survey, we find a wide dispersion across the quadrant, thus suggesting less "repetition" of the same reply or, to put it another way, high variability (diversity, dispersion) with respect to this question ${ }^{14}$. Thus, it is quite surprising to find the "great shifts" towards the right of the first factor. In fact, most of the variables located in the lower left-hand quadrant in the face-to-face survey "shift and disperse" towards the centre and the right in the telephone survey. Such is the case of the those claiming they "don't know" how to describe the current political and economic situation (PS-DK and ES-DK) and the political and economic situation compared with four years ago (EP-DK and PP-DK ); don't know their ideology (L.R-DK); have no opinion regarding the importance of the current elections in relation to previous ones (change-NA) and don't know whether or not a political change in Galicia is desirable (change-DK).

\footnotetext{
${ }^{12}$ It should be recalled that the data in question are those shown in Figure 1, "projecting" the categories from each method of data collection.

${ }^{13}$ Recall that the lower part of the second factor reveals the undefined responses: "don't know" and "no answer".

${ }^{14}$ Those who say they "don't know" to certain questions choose other categories in other questions; they do not repeat the same reply throughout the questionnaire as in the face-to-face survey.
} 
Figure 2.

Plot of categories: political and economic situation (current and one year ago) importance of current election, and desire for change on the main factorial plane resulting from the MCA.

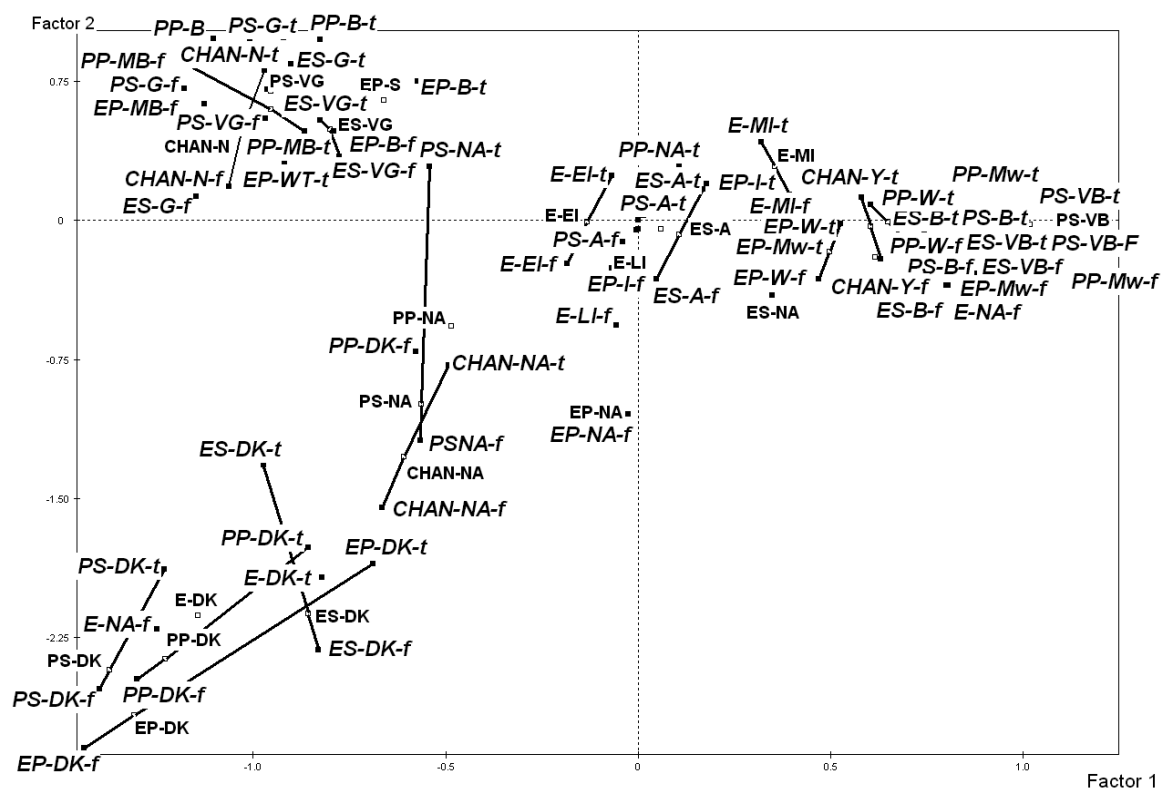

The symbols are explained in Table 1.

Source: Authors' own calculations using data from the CIS (2005).

This result might bear some relation with the lower non-response rate of the telephone survey (in contrast to the evidence found by the other survey mode and overall), but also with the higher quality of response obtained in the telephone survey; indicating that the "complacency" effect (satisficing) characterising telephone surveys in other contexts (Krosnick 1991: 213; Wessell et al. 2000: 7) is not found in this study. Krosnick (1991: 213) points out that considerable mental effort is required to respond properly to a survey because the respondent has to interpret the meaning and purpose of every question, search and retrieve all the information (stored in her memory), form an opinion from that information (make a judgment) and convey her opinion by selecting the appropriate response. Nevertheless, one of the consequences of telephone surveys is that subjects put less effort into their replies, which increases the number of unanswered questions, repetition of the same reply, the percentage of affirmative replies, etc. In short, the complacency effect suggests that telephone surveys yield lower quality information in contrast to the evidence found in the present study. 
As far as ideology and political vote (Figure 3 ) are concerned, it is interesting to note the change of location in the right-wing ideology and intention to vote PP if the elections were held tomorrow: in the face-to-face survey they appear in the middle lower part of the upper left-hand quadrant, only to "shift" upwards in the telephone survey. When interpreting this we need to bear in mind that at the time of the survey the PP was the governing party in Galicia with an absolute majority ${ }^{15}$, and also that certain events of the then recent past which had important repercussions for Galicia -one of them being the Prestige oil spill ${ }^{16}$ had not been forgotten. In many circles the two facts were associated, and the PP government was blamed for the mismanagement of the disaster; two and a half years later this still remained in the collective memory ("nunca mais"- "never again" the slogan used during the protests).

Figure 3.

Plot of categories: ideology, nationalism, voting intention and likelihood of voting on the main factorial plane resulting from the MCA.

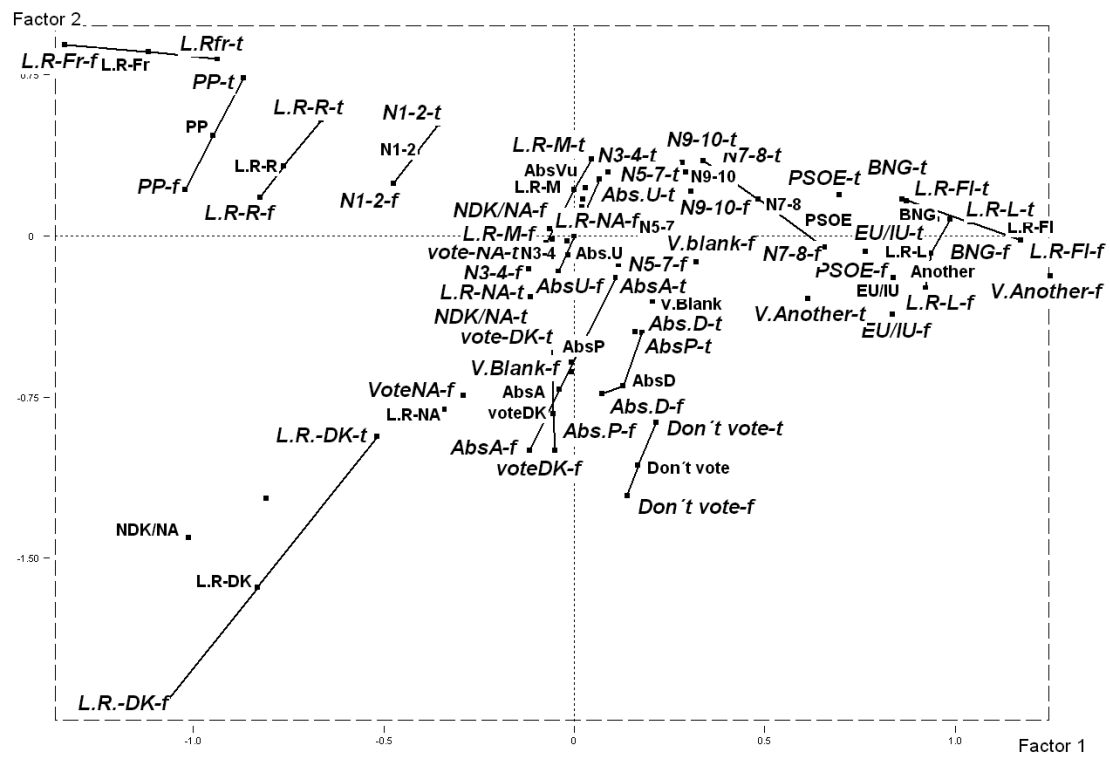

The symbols are explained in Table 1.

Source: Authors' own calculations using data from the CIS (2005).

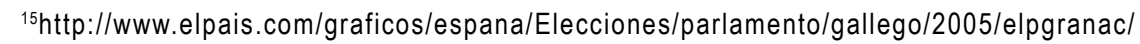
20050620elpepunac_2/Ges/

${ }^{16}$ Although the shipwreck occurred on November 13,2002 , its repercussions continued to fill the headlines of the national press for the following two months up to the end of January 2003. 
Thus, the "more extreme" views (leaning towards the People's Party and right-wing ideology) obtained via the telephone survey are the result of subjects responding to the survey with less pressure - at a time when the PP and rightwing attitudes were under strong criticism - because they did not have to face the interviewer in person. In other words, these results have to do with the fact that the telephone affords the survey respondent more privacy, who is therefore less likely to be influenced by the interviewer and feel less pressure to give the "socially acceptable" reply. Under this interpretation, the telephone is the most appropriate means in a situation of this nature since it allows respondents who support the governing party to state their intention to continue giving their support, even though the government's handling of the situation may have been less than satisfactory.

The joint analysis of all the variables, using socio-demographics as supplementary variables, provides a socio-demographic profile of the different opinion groups. As Figure

Table 2.

Categories of the socio-demographic variables and their markers on the plane

\begin{tabular}{|c|c|c|c|c|c|}
\hline Variable & Category & Marker & Variable & Category & Marker \\
\hline Age bracket & $\begin{array}{c}\text { 18-24 (years) } \\
25-34 \\
35-44 \\
45-54 \\
55-64 \\
65 \text { or over }\end{array}$ & $\begin{array}{l}\text { Age } 1 \\
\text { Age } 2 \\
\text { Age } 3 \\
\text { Age } 4 \\
\text { Age } 5 \\
\text { Age } 6\end{array}$ & Pop size & $\begin{array}{c}\text { Under } 2,000 \\
2,001-10,000 \\
10,001-50,000 \\
50,001-100,000 \\
100,001-400,000\end{array}$ & $\begin{array}{l}\text { PS1 } \\
\text { PS2 } \\
\text { PS3 } \\
\text { PS4 } \\
\text { PS5 }\end{array}$ \\
\hline Province & $\begin{array}{c}\text { Pontevedra } \\
\text { Ourense } \\
\text { A Coruña } \\
\text { Lugo }\end{array}$ & $\begin{array}{c}\text { Pontevedra } \\
\text { Ourense } \\
\text { A Coruña } \\
\text { Lugo }\end{array}$ & $\begin{array}{c}\text { Educational } \\
\text { level }\end{array}$ & $\begin{array}{l}\text { None or NA } \\
\text { Primary } \\
\text { Secondary } \\
\text { Vocational } \\
\text { studies } \\
\text { Bachelor's } \\
\text { degree } \\
\text { PhD or higher } \\
\text { Other }\end{array}$ & $\begin{array}{l}\text { Stud0 } \\
\text { Stud1 } \\
\text { Stud2 } \\
\text { Stud3 } \\
\text { Stud4 } \\
\text { Stud5 } \\
\text { Stud other }\end{array}$ \\
\hline Gender & $\begin{array}{l}\text { Male } \\
\text { Female }\end{array}$ & $\begin{array}{l}\text { Male } \\
\text { Female }\end{array}$ & Activity & $\begin{array}{l}\text { Employed } \\
\text { Unemployed } \\
\text { Retired or } \\
\text { pensioner } \\
\text { Student } \\
\text { Unpaid hou- } \\
\text { sework }\end{array}$ & $\begin{array}{l}\text { Employ } \\
\text { Unemploy } \\
\text { Retired } \\
\text { student } \\
\text { u.house }\end{array}$ \\
\hline
\end{tabular}


4 shows, subjects over the age of 54 , with very little education (primary or none), and residents in places with populations of less than 10,000 are located on the left-hand side of the factor, showing this to be the predominant demographic profile of those declaring a conservative ideology, no wish for a change of government, a tendency to vote PP, satisfaction with the economic and political situation (both current and in comparison with four years ago), and no (Galician) nationalist sentiment.

Located opposite them (on the right-hand side of the first factor) are those who exhibit a left-wing ideology, vote PSOE or IU, are dissatisfied with the economic and political situation, consider these elections more important than previous ones, and would like to see a change of government. These include a higher proportion of under $45 \mathrm{~s}$, educated to secondary level or higher and residents in large towns.

Figure 4.

A selection of the active and supplementary (socio-demographic) categories on the main factorial plane resulting from the MCA

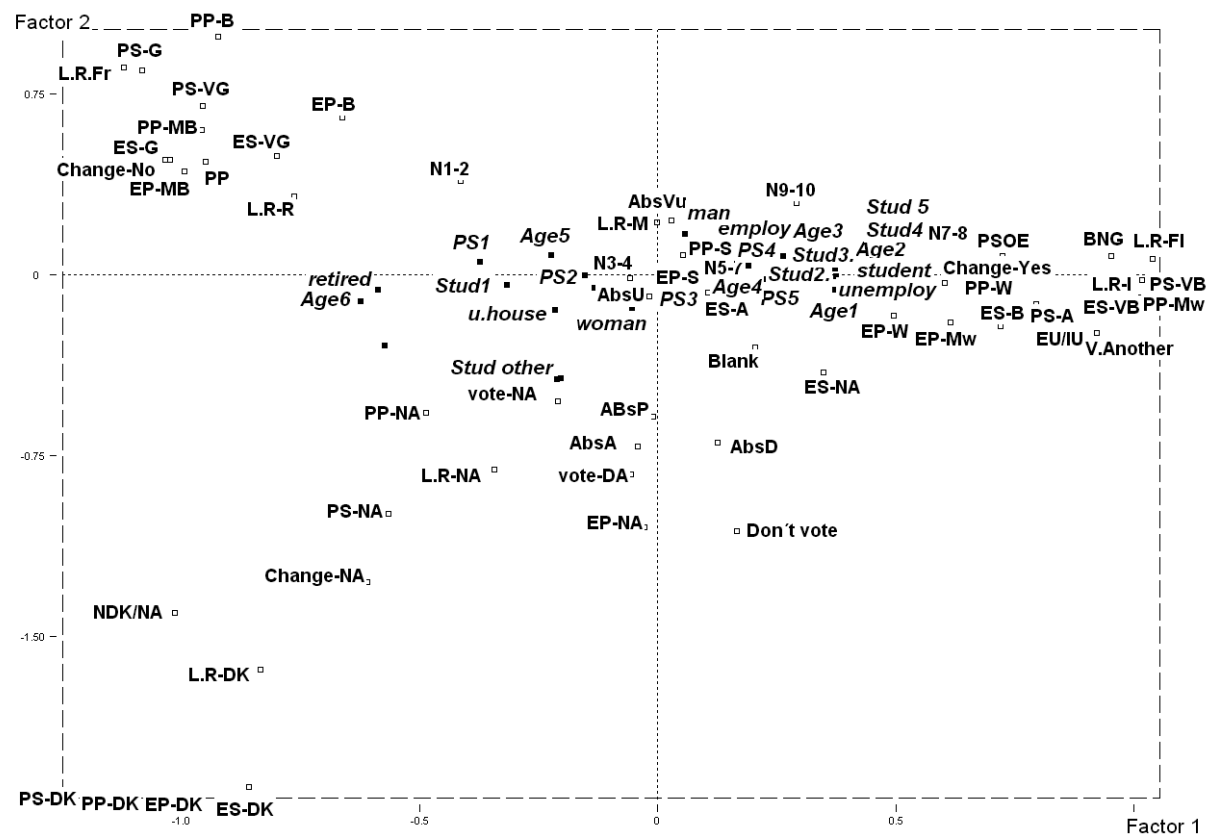

The symbols are explained in tables 1 and 2 .

Source: Authors' own calculations using data from the CIS (2005). 


\section{Conclusions}

This paper presents a new methodology using Multiple Correspondence Analysis to compare two survey modes: face-to-face versus telephone interviews. The main feature of the paper is that it enables the simultaneous analysis of all the variables relating to a topic and a global comparison of the survey modes in which their similarities and differences are analysed.

The comparison is performed essentially by graphic means. From all the plots obtained from the MCA, this study focuses mainly on the projection onto the same factorial plane of the supplementary points for the data obtained by each survey mode. A great deal of information is condensed into this graph, most of it with great interpretive potential. It gives the relative locations of the replies given to each question by survey mode, which can then be used to compare proportionate responses and even to detect general processes (systematically different responses or fluctuations).

The methodology was applied after first checking in a prior study (Abascal et al., in press) that similar samples were used in both surveys, even with respect to those variables (level of education, type of occupation, etc.) that were not controlled through the sample design. The findings can be summed up as follows:

The results present a common pattern, irrespective of the survey setting. The axes obtained in the factor analyses are similar by either survey mode. The first factor is the same in both cases, while some differences are found in the second factor. These differences emerge mainly in the "no answer" and "don't know" response categories

Demographic differences are found between the various opinion groups. In the group declaring a conservative ideology, no desire for a change of government, a tendency to vote PP, satisfaction with the economic and political situation (as it is and with respect to four years ago), and no nationalist sentiment, the proportion of low-educated, aged 54+, residents of places with populations of less than 10,000 is higher than in the sample as a whole. At the other end of the spectrum, in the group declaring a left-wing ideology, a tendency to vote PSOE or IU, dissatisfaction with the economic and political situation, a sense of the coming elections being more important than previous ones, and a desire for a change of government, the share of subjects under the age of 45 , with a secondary education or higher, and residing in major towns and cities is higher than in the sample as a whole.

A higher response rate was found in the telephone survey (contrasting with the evidence for other contexts), and a higher quality of response when the survey was administered by telephone. In contrast to what is suggested by other studies, the telephone ensures the survey respondent greater privacy, less influence from the interviewer, and thereby a reduction in the tendency to give "socially acceptable" replies.

The methodology presented in this paper for the comparative analysis of two specific data collection modes for pre-election surveys is applicable in a variety of contexts, that is, for data obtained through different data collection methods (telephone surveys, faceto-face surveys, online surveys, traditional questionnaires, etc.) in different geographical locations (cities, regions, countries, etc.) or different points of time (dynamic or tendency 
surveys). While different sample sizes can also be used, their structures must be similar in the sense described throughout this paper. Based on all these features, we believe this to be a highly versatile methodology.

\section{REFERENCES}

Abascal, E. and I. Grande. 2005. Análisis de encuestas. Madrid: ESIC.

Abascal, E., V. Díaz de Rada, N. García-Lautre and M. Landaluce. "Comparing face to face and telephone surveys in terms of sampling representativeness: a multidimensional analysis." Quality \& Quantity. International Journal of Methodology. junio 2010 DOI 10.1007/s 11135-010-9353-5.

Alvira Martín, F. 2004. La encuesta: una perspectiva general metodológica. Cuadernos Metodológicos, $\mathrm{n}^{0}$ 35. Madrid: CIS.

Beck, F., S. Legleye and P. Peretti-Watel. 2004. "Using the telephone in general population surveys on drugs". Pp. 113-140 in T. Decorte and D.J. Korf (Eds.), European studies on drugs and drug policy. Brussels: VUB Press.

Benzécri J.P. 1979. "Sur le calcul des taux d'inertie dans l'analyse d'un questionnaire." Les cahiers de l'Analyse des Donnés 4, n 3: 377-366.

Biemer, P.P. 2001. "Non-response bias and measurement bias in a comparison of face to face and telephone interviewing." Journal of Official Statistics 17: 295-320.

Blumberg, S.J., J.V. Luke, M.L. Cynamon and M. Frankel. 2008. "Recent trends in household telephone coverage in the United States." Pp. 56-86 in J. Lepkowski et al. (eds). Advances in telephone survey methodologies. New York: Willey.

Bowers, J. and M.J. Ensley. 2003. Issues in Analyzing Data from the Dual-Mode 2000 American National Election Study, NES Technical Report.

Centro de Investigaciones Sociológicas 2005. Preelectoral de Galicia. Elecciones autonómicas 2005, Madrid: Centro de Investigaciones Sociológicas, research number 2608.

Czaja, R. y J. Blair. 1996. Designing Surveys. California: Pine Forge.

Day, N.A. et al. 1995. "Maximizing response to surveys in health-program evaluation at minimum-cost using multiple methods." Evaluation Review 19: 436-450.

De Leeuw, E. and J. Van der Zouwen. 1988. "Data quality in telephone and face to face surveys: a comparative meta-analysis". Pp. 283-299. In R.M. Groves et al. (eds), Telephone Survey Methodology, New York: Wiley.

De Leeuw, E. 2008. "Choosing the method of data collection”. Pp. 113-135, in E.D. de Leeuw; J.J. Hox y D.A. Dillman (eds.) International Handbook of Survey Methodology. Nueva York: Lawrence Erlbaum Associates y Asociación Europea de Metodología. 
Dillman, D.A. 2008. "The logic and psychology of constructing questionnaires". Pp. 171-175 in E.D. de Leeuw; J.J. Hox y D.A. Dillman (eds.). International Handbook of Survey Methodology. Nueva York: Lawrence Erlbaum Associates y Asociación Europea de Metodología.

Ellis, C. and Krosnick, J.A. 1999. Comparing telephone and face to face surveys in terms of sample representativeness: a Meta-Analysis of Demographics Characteristics. Ann Arbor, University of Michigan: NES (National Election Studies) Technical Reports. Retrieved March 1, 2005 from: www. umich.edu/nes/resources/papers/papers.htm.

Galán, I., F. Rodríguez Artalejo and B. Zorrilla. 2004. "Comparación entre encuestas telefónicas y encuestas "cara a cara" domiciliarias en la estimación de hábitos de salud y prácticas preventivas." Gaceta Sanitaria 18: 440-50.

Goyder, J. 1985. "Face to face interviews and mailed questionnaires: the net difference in response rate." Public Opinion Quarterly 49: 234-252.

Green, M.C., J.A. Krosnick and A.L. Holbrook. 2001. "The survey response process in telephone and faceto-face surveys. Differences in respondent satisficing and social desirability response bias". Retrieved June 23, 2004 from: www.umich.edu/nes/resources/techrpts/tech-abs/tech-ab62.htm.

Grenacre M.J. and J. Blasius (eds) 2006. Multiple Correspondence Analysis and Related Methods. London: Chapman \& Hall / CRC.

Groves, R.M. 1989. Survey Error and Survey Cost. New York: Wiley.

Groves, R.M y R. Kahn. 1979. Surveys by Telephone. New York: Academic Press.

Hox, J.J. and Deleeuw, E. 1994. "A comparison of non-response in mail, telephone, and face-to-face surveys." Quality and Quantity 28: 329-344.

Kalton, G. 2000. "Developments in survey research in the past 25 years." Survey Methodology 26: 3-10.

Krosnick, J.A. 1991. "Response strategies for coping with the cognitive demands of attitude measures in surveys." Applied Cognitive Psychology 5: 213-236.

Krosnick, J.A. 1999. "Survey research." Annual Review of Psychology 50: 537-567.

Kuusela, V., M. Callegaro and V. Vehovar. 2008. "The influence of mobile telephones on telephone surveys" Pp. 87-112 in J. Lepkowski et al. (eds). Advances in telephone survey methodologies. New York,Willey.

Lavrakas, P.J. 1993. Telephone Survey Methods. Newbury Park, CA: Sage, Applied Social Research Methdods Series, vol 7.

Lebart L., A. Morineau and M. Piron. 1998. Statistique exploratoire multidimensionelle. París: Dunod Martínez de Luna, I. 2008. "Encuestas de opinión: de la teoría a la práctica." Metodología de encuestas 10: 7-26.

Massey, J.T. 1988. "An overview of telephone coverage" Pp. 3-8 in R.M. Groves et al. Telephone Survey Methodology. New York: Wiley. 
Méndez Lago, M. and R. Martínez Casinello. 2007. Encuestas telefónicas vs. presenciales: análisis de la encuesta pre-electoral del CIS de las elecciones gallegas de 2005. $15^{\text {th }}$ Seminar on Political and Sociological Surveys, organized by the Spanish Association for Opinion, Marketing and Market research studies (AEDEMO), Madrid, 15-16 November 2007.

Nicolaas, G., K. Thomson and P. Lynn. 2000. The Feasibility of Conducting Electoral Surveys in the UK by telephone. London, National Centre for Social Research.

Presser, S. and L. Stinson. 1998. "Data collection mode and social desirability bias in self-reported religious attendance." American Sociological Review 63: 137-145.

Salinas, J.M., A. Calvo and M.C. Aguilar. 2004. "Un análisis comparativo entre la entrevista telefónica y la entrevista presencial en la determinación de la prevalencia de los juegos de azar." Metodología de Encuestas 6, n 2: 119-132.

Sykes, W. and M. Collins. 1998. "Effects of Mode of Interview: experiment in the UK" Pp. 283-299 in R.M. Groves et al. (eds), Telephone Survey Methodology, New York, Wiley.

Tourangeau, R. 2004. "Survey research and societal change." Annual Review of Psychology 55: 775801.

Voogt, R.J.J. and Saris, W.E. 2005. "Mixed mode designs: finding the balance between nonresponse bias and mode effects." Journal of Official Statistics 21: 367-387.

Wessell, D., W. Rahn and T. Rudolph. 2000. An analysis of the 1998 NES Mixed-Mode Design. Ann Arbor, University of Michigan: NES (National Election Studies) Technical Reports. Retrieved March 1, 2005 from: www.umich.edu/ nes/resources/papers/papers.htm.

Willems, P. y P. Oosterveld. 2003. "The best of both worlds." Marketing Research 25: 23-26.

ELENA ABASCAL FERNÁNDEZ Ph.D. in Economics and Business, Tenured lecturer in Statistics and Operations Research. Her research interests lie in multivariate data analysis and survey analysis.

VIDAL DÍAZ DE RADA Ph.D. in Sociology, Bachelor's degree in Marketing Research and Techniques, lecturer in the Public University of Navarra, Department of Sociology. His research interests lie in the methodology and sociology of consumer research and the study of consumer behaviour.

IGNACIO GARCÍA LAUTRE Ph.D. in Business Administration and Management, Ph. D. and nontenured lecturer in Statistics and Operations Research. His research interests lie in multivariate data analysis and survey analysis.

M. ISABEL LANDALUCE CALVO Ph.D. in Economics and Business, tenured lecturer in Applied Economics, specialising in Quantitative Methods for Economics and Business. Her research interests lie in multivariate data analysis and survey analysis.

RECEIVED: 07 February 2011

ACCEPTED: 01 December 2011

Published online: 28 June 2012 